\title{
Coordination Polymers Consisting of Unusual Motifs. Synthesis and Properties of Silver(I) and Copper(II) Complexes of Triethanolaminetriisonicotinate
}

\author{
Tae Hwan Noh, Jung Woon Lee, Young-A Lee, Ji Eun Lee, ${ }^{\ddagger}$ Shim Sung Lee, ${ }^{\ddagger}$ and Ok-Sang Jung \\ Department of Chemistry: Pusan National Lniversity Pusan 609-735, Korea. ${ }^{*}$ E-mail oksjungapusanac.kr \\ ${ }^{\dagger}$ Department of Chemstry, Chonbuk Wational Lniversity, Jeonit 561-756, Korea \\ ${ }^{\ddagger}$ Department of Chemistry, Gyeongsang National Lniversitvi, Jinju 660-701, Korea \\ Received November 20, 2007
}

\begin{abstract}
Reaction of $\mathrm{AgNO}_{3}$ with triethanolaminetriisonicotinate $(\mathrm{L})$ produces $\mathrm{l}$ D coordination polymer of $\left[\mathrm{Ag}_{3}(\mathrm{~L})_{2}\right]\left(\mathrm{NO}_{3}\right)_{3}$ and the same treatment of $\mathrm{Cu}\left(\mathrm{NO}_{2}\right)_{2}$ with $\mathrm{L}$ gives $\mathrm{ID}$ coordination polymer of $\left[\mathrm{Cu}(\mathrm{L})_{3}\right]\left(\mathrm{NO}_{3}\right)_{2}$. The nonrigid triethanolaminetriisonicotinate acts as a $\mu_{3}$-bridged tridentate for $\left[\mathrm{Ag}_{3}(\mathrm{~L})_{2}\right]-$ $\left(\mathrm{NO}_{3}\right)_{3}$ and a $\mu_{2}$-bridged bidentate for $\left[\mathrm{Cu}(\mathrm{L})_{2}\right]\left(\mathrm{NO}_{3}\right)_{2}$ to produce unusual motifs. The $\mathrm{NO}_{3}{ }^{-}$anions can be smoothly exchanged by $\mathrm{PF}_{6}{ }^{-}$anions in an aqueous suspension without destruction of the skeletal structure.
\end{abstract}

Key Words : Anion exchange. Copper(II) complexes, Crystal structures, One dimensional coordination polymers, Silver(I) complexes

\section{Introduction}

Rational construction of metal coordination complexes with specific motifs is a thematic issue since the coordination materials have potential applications such as molecular separation. toxic materials adsorption. molecular containers. ion exchangers. molecular recognition, and luminescent sensors ${ }^{1-6}$ Thus. various frameworks have been constructed by the coordination reaction of metal ions with designed organic linkers ${ }^{7-11}$ even though serendipitous motifs have been frequently formed owing to the presence of unpredictable weak interactions such as hydrogen bonds. van der Waals forces. metal-metal interactions. and $\pi-\pi$ interactions. ${ }^{y-2}$ Appropriate angles. lengths and flexible components of multidentate $\mathrm{N}$-donor linkers play important roles in the self-assembly of the tailor-made complexes and thus the syntheses of new organic linkers are one of significant works in the field. In this context recently. we have demonstrated that various pyridyl ligands are useful tectonics for desirable functional coordination materials. ${ }^{21-28}$ Since conformationally nonrigid organic ligands were used to obtain unusual motifs. we have been interested in the design and sy'nthesis of metal complexes of conformationally nonrigid pyridyl ligands. ${ }^{.9 .31}$ In order to expand the chemistry metal complexes containing triethanolaminetriisonicotinate have been prepared and characterized. Here. we report new one dimensional coordination polymers consisting of unusual motifs by the reactions of metal nitrates $\left(\mathrm{Cu}\left(\mathrm{NO}_{3}\right)_{2}\right.$ and $\left.\mathrm{AgNO}_{3}\right)$ with the triethanolaminetriisonicotinate. Our previous results have shown that the triethanolaminetriisonicotinate is an interesting ligand. ${ }^{31-33}$

\section{Experimental}

Materials and Measurements. $\mathrm{Cu}\left(\mathrm{NO}_{3}\right)_{2}$ and $\mathrm{AgNO}_{3}$ were purchased from Aldrich and used without purification. Triethanolaminetriisonicotinate (L) was prepared according to the literature procedure. ${ }^{23}$ Elemental analyses $(\mathrm{C} . \mathrm{H}, \mathrm{N})$ were performed on crystalline samples by the Advanced Analytical Center at KBSI with a Perkin-Elmer $2400 \mathrm{CHNS}$ Analyzer. Infrared spectra were obtained on a Perkin Elmer 16F PC FTIR spectrophotometer with samples prepared as $\mathrm{KBr}$ pellets. Thermal analy ses were performed under a nitrogen atmosphere at a scan rate of $10^{\circ} \mathrm{C} / \mathrm{min}$ with a Stanton Red Croft TG 100

Preparation of $\left[\mathrm{Ag}_{3}(\mathrm{~L})_{2}\right]\left(\mathrm{NO}_{3}\right)_{3}$. A methanol solution $(6$ $\mathrm{mL}$ ) of L (93 mg. $0.20 \mathrm{mmol})$ was slowly diffused into an aqueous solution $(6 \mathrm{~mL})$ of $\mathrm{AgNO}_{3}(51 \mathrm{mg} .0 .30 \mathrm{mmol}$ ). Colorless crystals of $\left[\mathrm{Ag}_{3}(\mathrm{~L})_{2}\right]\left(\mathrm{NO}_{2}\right)_{3}$ were formed at the interface. and were obtained in 6 days in $70 \%$ yield. Mp. 185 ${ }^{\circ} \mathrm{C}(\mathrm{dec})$. Calcd for $\mathrm{C}_{48} \mathrm{H}_{48} \mathrm{~N}_{11} \mathrm{O}_{21} \mathrm{Ag}_{2}: \mathrm{C} .40 .08, \mathrm{H} .3 .36 . \mathrm{N}$. 10.71. Found: C. 39.90: H. 3.30: N. 10.60. IR $\left(\mathrm{KBr} . \mathrm{cm}^{-1}\right)$ : $v(\mathrm{C}=\mathrm{O}) .1721(\mathrm{~s}), v\left(\mathrm{NO}_{2}\right), 1371(\mathrm{~s}), 1123(\mathrm{~s}) .74(\mathrm{~s}), 682(\mathrm{~s})$.

Preparation of $\left[\mathrm{Cu}(\mathrm{L})_{2}\right]\left(\mathrm{NO}_{3}\right)_{2}$. A methanol solution $(6$ $\mathrm{mL}$ ) of $\mathrm{L}(93 \mathrm{mg} .0 .20 \mathrm{mmol})$ was slowly diffused into an aqueous solution $(6 \mathrm{~mL})$ of $\mathrm{Cu}\left(\mathrm{NO}_{3}\right)_{2} \cdot 2.5 \mathrm{H}_{2} \mathrm{O}(23 \mathrm{mg} .0 .10$ mimol). Blue crystals of $\left[\mathrm{Cu}(\mathrm{L})_{2}\right]\left(\mathrm{NO}_{3}\right)_{2}$ were formed at the interface. and were obtained in 6 days in $75 \%$ yield. Mp. 190 ${ }^{\circ} \mathrm{C}(\mathrm{dec})$. Calcd for $\mathrm{C}_{48} \mathrm{H}_{48} \mathrm{~N}_{10} \mathrm{O}_{18} \mathrm{~F}_{18} \mathrm{Cu}$ : C. $51.64 . \mathrm{H}, 4.33$ N. 12.55. Found: C. 52.20: H. 4.29: N. 12.60. IR ( $\mathrm{KBr}$. $\left.\mathrm{cm}^{-1}\right): \nu(\mathrm{C}=\mathrm{O}), 1718(\mathrm{~s}), v\left(\mathrm{NO}_{3}\right), 1287(\mathrm{~s}), 1131(\mathrm{~s}), 75(\mathrm{~s})$. 690(s).

Anion Exchange of $\left[\mathrm{Ag}_{3}\left(\mathrm{~L}_{2}\right]\left(\mathrm{NO}_{3}\right)_{3}\right.$ with $\mathrm{NaBF}_{4}$. An aqueous solution $\left(3 \mathrm{~mL}\right.$ ) of $\mathrm{NaBF}_{4}(33 \mathrm{mg} .0 .3 \mathrm{mmol})$ was added to an aqueous suspension ( $3 \mathrm{~mL}$ ) of microcrystalline $\left[\mathrm{Ag}_{3}(\mathrm{~L})_{2}\right]\left(\mathrm{NO}_{3}\right)_{3}(90 \mathrm{mg} .0 .1 \mathrm{mmol})$ at room temperature. The reaction mixture was stirred and each precipitate was monitored after $24 \mathrm{~h}$ by IR spectra. The anion exchange of the $\mathrm{NO}_{3}^{-}$analogue with other $\mathrm{NaX}\left(\mathrm{X}^{-}=\mathrm{PF}_{6}^{-} . \mathrm{ClO}_{4}^{-}\right)$was carried out by the same procedure. The $\mathrm{BF}_{4}{ }^{-}$anion was partially exchanged (elemental analysis indicates the mixture of $25 \% \mathrm{NO}_{3}^{-}$and $75 \% \mathrm{BF}_{4}{ }^{-}$anions (Calcd for $\mathrm{C}_{48} \mathrm{H}_{48} \mathrm{~N}_{10.25-}$ $\mathrm{O}_{18.78} \mathrm{Bi}_{17.75} \mathrm{~F}_{3} \mathrm{Ag}_{3}:$ C. 39.57, H. 3.32. N. 9.85. Found: C. 39.2: H. 3.30: N. 9.70). but $\mathrm{PF}_{6}^{-}$was completely exchanged 
Table 1. Crystallographic Data for $\left[\mathrm{Ag}_{3}(\mathrm{~L})_{2}\right]\left(\mathrm{NO}_{3}\right)_{3}$ and $\left[\mathrm{Cu}(\mathrm{L})_{2}\right]-$ $\left(\mathrm{NO}_{3}\right)_{2}$

\begin{tabular}{|c|c|c|}
\hline & {$\left[\mathrm{Ag}_{3}(\mathrm{~L})_{2}\right]\left(\mathrm{NO}_{3}\right)_{3}$} & {$\left[\mathrm{Cu}(\mathrm{L})_{2}\right]\left(\mathrm{NO}_{2}\right)=$} \\
\hline formula & $\mathrm{C}_{24} \mathrm{H}_{24} \mathrm{~N}_{5} \mathrm{O}_{10.5} \mathrm{Ag}_{1.5}$ & $\mathrm{C}_{48} \mathrm{H}_{48} \mathrm{~N}_{10} \mathrm{O}_{18} \mathrm{Cu}$ \\
\hline fw & 719.29 & 1116.50 \\
\hline space group & monoclinic, $(C 2 c$ & triclinic, $P I b a r$ \\
\hline$a / \AA$ & $27.822(1)$ & $9.3620(6)$ \\
\hline$b / \AA$ & $12.7614(6)$ & $11.3576(8)$ \\
\hline$d \AA$ & $19.3950(9)$ & $12.7103(8)$ \\
\hline$\alpha /$ deg & & $105.904(1)$ \\
\hline$\beta / \mathrm{deg}$ & $129.934(1)$ & $102.714(1)$ \\
\hline$y /$ deg & & $101.328(1)$ \\
\hline$W / A^{3}$ & $5280.2(4)$ & $1219.5(1)$ \\
\hline 2 & 8 & 1 \\
\hline$d_{\text {cadud }} / g \mathrm{~cm}^{-3}$ & 1.810 & 1.520 \\
\hline$\mu, \mathrm{nm}^{-1}$ & 1.194 & 0.537 \\
\hline \multicolumn{3}{|l|}{$R[I>2 \sigma(I)]$} \\
\hline$R_{\mathrm{l}}{ }^{i}$ & 0.0424 & 0.0514 \\
\hline$w R_{2}^{b}$ & 0.0748 & 0.1047 \\
\hline \multicolumn{3}{|l|}{$R$ (all data) } \\
\hline$R_{1}^{a}$ & 0.0751 & 0.0806 \\
\hline$w R_{2}^{b}$ & 0.0849 & 0.1160 \\
\hline
\end{tabular}

(Calcd for $\mathrm{C}_{48} \mathrm{H}_{4 \S} \mathrm{N}_{\S} \mathrm{O}_{1:} \mathrm{F}_{18} \mathrm{P}_{3} \mathrm{Ag}_{3}:$ C. 34.17, H. 2.87. N, 6.64. Found: C. $34.20 ;$ H. $2.90: \mathrm{N}, 6.60$ ).

$\mathrm{X}$-ray Crystallography. All X-ray data were collected on a Bruker SMART automatic diffractometer with a graphitemonochromated Mo $\mathrm{K} \alpha$ radiation $(\hat{\lambda}=0.71073 \hat{\mathrm{A}})$ and a CCD detector at ambient temperature. The 45 frames of two dimensional diffraction images were collected and processed to obtain the cell parameters and orientation matrix. During the data collection. three standard reflections monitored after every hour did not reveal any systentatic variation in intensity. The data were corrected for Lorentz and polarization effects. Absorption effects were corrected by the SADABS method. The structures were solved by the Patterson method (SHELXS 97) and refuned by full-matrix least square techniques (SHELXL 97) ${ }^{34}$ The non-hydrogen atons were refuned anisotropically. Hydrogen atoms were placed in calculated positions and refined only for the isotropic thermal factors. Crystal parameters and procedural information corresponding to data collection and structure refinement are given in Table 1. Crystallographic data for the $\left[\mathrm{Ag}_{3}(\mathrm{~L})_{2}\right]\left(\mathrm{NO}_{3}\right)_{3}$ and $\left[\mathrm{Cu}(\mathrm{L})_{2}\right]\left(\mathrm{NO}_{3}\right)_{2}$ complexes are deposited at the Cambridge Crystallographic Data Centre under supplementary publication numbers CCDC-662794 and 662795. respectively: Copies of available material may be obtained ob application to CCDC. 12 Union Road. Cambridge CB2 1EZ. UK. fax: +441223336033 . or e-mail: deposit $a$ scedc cam ac.uk.

\section{Results and Discussion}

Synthesis. The slow diffusion of $\mathrm{Cu}\left(\mathrm{NO}_{3}\right)_{2}$ in methanol with a flexible multidentate $\mathrm{L}$ in dichloromethane produced blue crystals while the same treatment of $\mathrm{AgNO}_{3}$ in

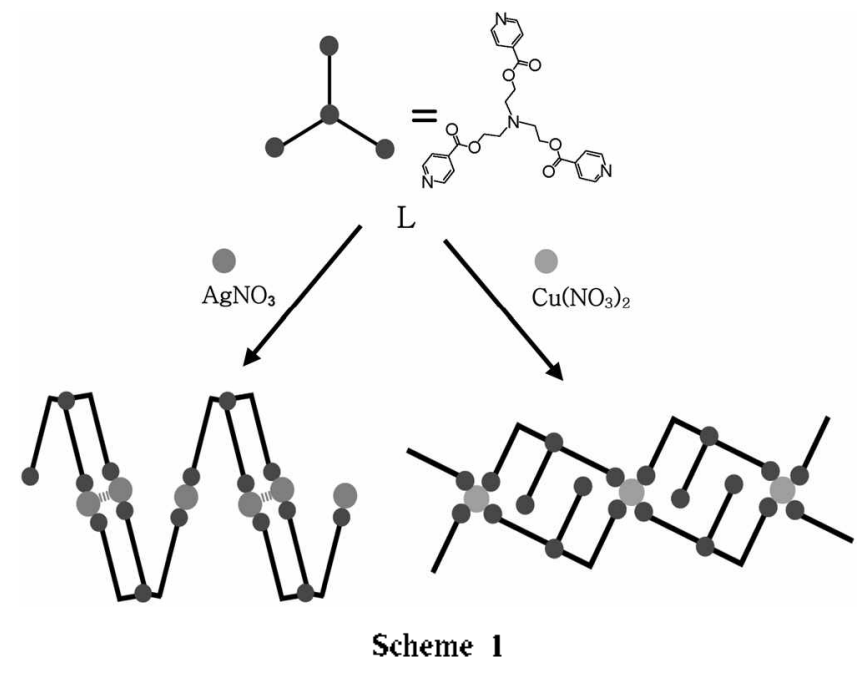

methanol with $\mathrm{L}$ in dichloromethane produced colorless crystals suitable for X-ray crystallography. They are very stable one dimensional coordination polymers in contrast to discrete cobalt(II or III) and palladium(II) complexes of the ligand. ${ }^{31,33}$ The products are insoluble in common organic solvents such as toluene, benzene. tetrahydrofuran. chloroform. dichloromethane. and acetone. The products are slowly dissociated in $\mathrm{Me}_{2} \mathrm{SO}$ and N.N-dimethylformamide. The reactions were initially carried out at the mole ratio of $1: 2$ $(\mathrm{M}: \mathrm{L})$, but the same compounds were obtained irrespective of the mole ratio. That is. the formation of the products was not significantly affected by the change of reactant mole ratio and concentration, indicating that the compound is a favorable species. The silver(I) ion gave $\left[\mathrm{Ag}_{3}(\mathrm{~L})_{2}\right]\left(\mathrm{NO}_{3}\right)_{3}$ unit whereas the copper ion produced $\left[\mathrm{Cu}(\mathrm{L})_{2}\right]\left(\mathrm{NO}_{3}\right)_{2}$ unit as shown in Scheme 1.

Crystal Structures. X-ray characterizations on both single crystals have provided unique one dimensional coordination polymeric species of the building blocks, $\left[\mathrm{Ag}_{3}(\mathrm{~L})_{2}\right]\left(\mathrm{NO}_{3}\right)_{3}$ and $\left[\mathrm{Cu}(\mathrm{L})_{3}\right]\left(\mathrm{NO}_{3}\right)_{2}$ (Scheme 1). Their crystal structures are depicted in Figures 1 and 2. and the relevant bond distances and angles are listed in Tables 2 and 3. For $\left[\mathrm{Ag}_{3}(\mathrm{~L})_{3}\right]\left(\mathrm{NO}_{3}\right)_{3}$. L connects three $\mathrm{Ag}(\mathrm{I})$ ions in a bridged tridentate mode to give an unusual zigzag strand consisting of alternate single strand and double strand. The $\mathrm{Ag}-\mathrm{N}$ bond lengths are in the range of 2.177(3)-2.268(3) A The local geometry around the silver(I) ion approximates to a linear arrangenent $\left(\mathrm{N}-\mathrm{Ag}-\mathrm{N}=174.9(1)^{\circ}\right.$ for a double strand; $167.9(2)^{\circ}$ for a single strand). The nitrate anion very weakly interacts with the silver(I) ion. and thus the nitrate acts as a counteranion rather than a ligand (the distances of $\left.\mathrm{Ag} \cdots \mathrm{O}\left(\mathrm{NO}_{3}{ }^{-}\right)=2.67-3.24 \AA\right)$. The most interesting feature is that two pyridyl nitrogen donors of $\mathrm{L}$ coordinate to two $\mathrm{Ag}(\mathrm{I})$ ions via $\pi-\pi$ interaction $(-3.5 \AA)$ (double strand). and the remaining one pyridyl nitrogen donor coordinates to the other side $\mathrm{Ag}(\mathrm{I})$ ion (single strand). The $\pi-\pi$ interaction induces the Ag-Ag interaction (3.2882(6) A). Thus. overall structure is an unusual zigzag $1 \mathrm{D}$ coordination polymer consisting of alternate single strand and double strand as shown in Figure 1. 


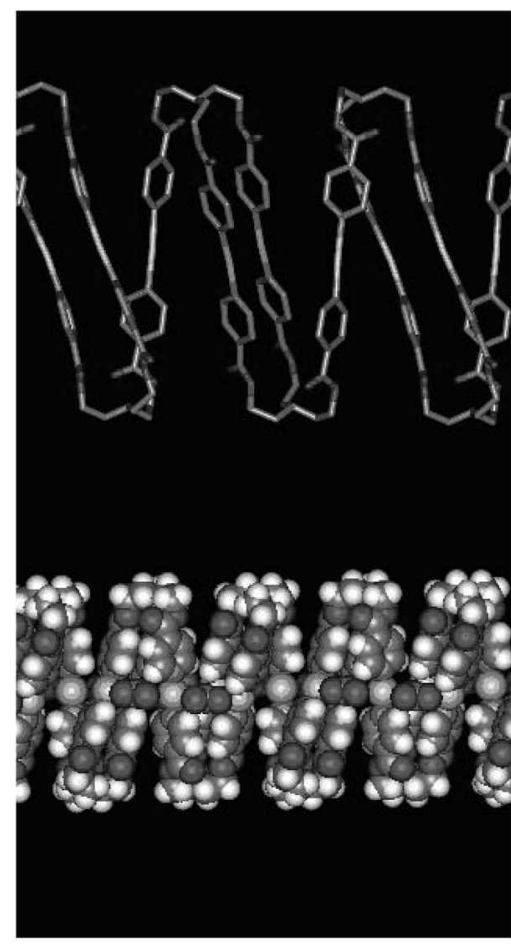

Figure 1. $\mathrm{X}$-ray crystal structure of $\left[\mathrm{Ag}_{3}(\mathrm{~L})_{2}\right]\left(\mathrm{NO}_{3}\right)_{3}$.

For $\left[\mathrm{Cu}(\mathrm{L})_{2}\right]\left(\mathrm{NO}_{3}\right)_{2}$ (Figure 2 ), L acts as a bridged bidentate. and the third nitrogen donor remains free. Thus. each copper(II) ion is coordinated by four nitrogen donors. and may be ascribed to a pseudo octahedral $\mathrm{N}_{4} \mathrm{O}_{2}$ coordination arrangement with two $\mathrm{NO}_{3}{ }^{-}$anions in a trans position $\left(\mathrm{Cu} \cdots \mathrm{O}=2.524(2) \AA: \mathrm{O} \cdots \mathrm{Cu} \cdots \mathrm{O}=180.0^{\circ}\right)$ and four pyridine units in a basal plane $(\mathrm{Cu}-\mathrm{N}=2.009(2) \mathrm{A}$ and 2.047(2) A). That is. a $C_{2}$ symmetric rectangle $(8.40 \AA \times 11.77 \AA$ ) with two free pyridyl groups is a motif of the coordination polymer. The $\mathrm{NO}_{3}^{-}$anions are located at the apical position of the square planar copper(II) ion. indicating the presence of weak electrostatic interaction. The red-shifted $\mathrm{NO}_{3}{ }^{-} \mathrm{IR}$ band $\left(1287 \mathrm{~cm}^{-1}\right)$ relative to that of above $\left[\mathrm{Ag}_{3}(\mathrm{~L})_{2}\right]\left(\mathrm{NO}_{3}\right)_{3}$ $\left(1371 \mathrm{~cm}^{-1}\right)$ seems to result from the weak electrostatic interaction. A significant feature is an unprecedented rectangle unit containing two free pyridyl groups. The two free pyridyl groups within the intrarectanglar unit are oriented toward different sides. and thus the $\pi$-stacking between the free pyridyl groups does not exist. The two donors may be applicable to the coordination site for other metal cations

Physicochemical Properties. The thermogravimetric analyses (TGA) show that the crystals are thermally stable up to $190^{\circ} \mathrm{C}$ for $\left[\mathrm{Ag}_{3}(\mathrm{~L})_{2}\right]\left(\mathrm{NO}_{3}\right)_{3}$ (the remaining residue 35 wt. \%) and up to for $200^{\circ} \mathrm{C}$ for $\left[\mathrm{Cu}(\mathrm{L})_{2}\right]\left(\mathrm{NO}_{3}\right)_{2}$ (the remaining residue 18 wt. \%). The products drastically decompose at the range of $190-250^{\circ} \mathrm{C}$ for $\left[\mathrm{Ag}_{3}(\mathrm{~L})_{2}\right]\left(\mathrm{NO}_{3}\right)_{3}$ and $200-280^{\circ} \mathrm{C}$ for $\left[\mathrm{Cu}(\mathrm{L})_{2}\right]\left(\mathrm{NO}_{3}\right)_{2} \cdot\left[\mathrm{Cu}(\mathrm{L})_{2}\right]\left(\mathrm{NO}_{3}\right)_{2}$ is thermally more stable than $\left[\mathrm{Ag}_{3}(\mathrm{~L})_{2}\right]\left(\mathrm{NO}_{3}\right)_{3}$ even though the copper(II) compound has two free pyridyl groups. Such a fact indicates that the free pyridyl groups are rigid and stable in the solid state.

A combination of appropriate length. N-position. Lewis

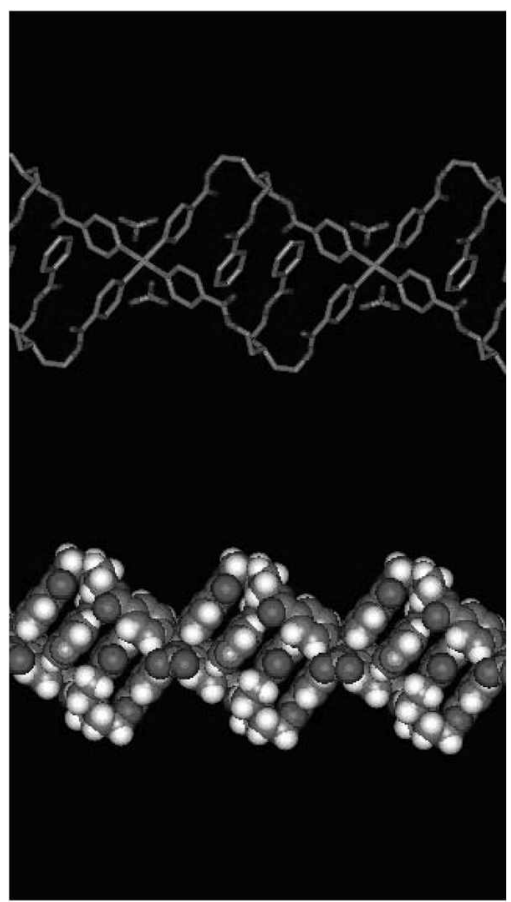

Figure 2. X-ray crystal structure of $\left[\mathrm{Cu}(\mathrm{L})_{2}\right]\left(\mathrm{NO}_{3}\right)_{2}$.

Table 2. Selected Bond Distance and Angles of $\left[\mathrm{Ag}_{5}(\mathrm{~L})_{2}\right]\left(\mathrm{NO}_{3}\right)_{3}$

$\begin{array}{ll}\mathrm{Ag}(1)-\mathrm{N}(1) & 2.177(3) \\ \mathrm{Ag}(1)-\mathrm{N}(3) \# 1 & 2.187(3) \\ \mathrm{Ag}(1)-\mathrm{Ag}(1) \# 1 & 3.2882(6) \\ \mathrm{Ag}(2)-\mathrm{N}(2) \# 2 & 2.268(3) \\ \mathrm{Ag}(2)-\mathrm{N}(2) & 2.268(3) \\ \mathrm{N}(1)-\mathrm{Ag}(1)-\mathrm{N}(3) \# 1 & 174.9(1) \\ \mathrm{N}(1)-\mathrm{Ag}(1)-\mathrm{Ag}(1) \# 1 & 77.08(7) \\ \mathrm{N}(3) \# 1-\mathrm{Ag}(1)-\mathrm{Ag}(1) \# 1 & 107.88(7) \\ \mathrm{N}(2) \# 2-\mathrm{Ag}(2)-\mathrm{N}(2) & 167.9(2) \\ \mathrm{C}(5)-\mathrm{N}(1)-\mathrm{Ag}(1) & 121.6(2) \\ \mathrm{C}(1)-\mathrm{N}(1)-\mathrm{Ag}(1) & 120.8(2) \\ \mathrm{C}(13)-\mathrm{N}(2)-\mathrm{Ag}(2) & 121.4(2) \\ \mathrm{C}(9)-\mathrm{N}(2)-\mathrm{Ag}(2) & 121.3(2) \\ \mathrm{C}(17)-\mathrm{N}(3)-\mathrm{Ag}(1) \# 1 & 120.9(2) \\ \mathrm{C}(21)-\mathrm{N}(3)-\mathrm{Ag}(1) \# 1 & 121.8(3)\end{array}$

Symmetry transfomations used to generate equivalent atoms: $+5 \mathrm{l}-\mathrm{x}$. $-y-2 .-2-1+2-x . y-2-32$

basicity of the flexible nitrogen donor ligand. and metal coordination geometry seems to construct the coordination polymers consisting of unusual motifs. The cationic skeletal structures are basically stable, and thus the counteranion exchange was smoothly carried out without destruction of skeletal structure in aqueous suspension state. According to the literature procedure. ${ }^{35,36}$ the anion exchange of $\left[\mathrm{Ag}_{3}(\mathrm{~L})_{2}\right]\left(\mathrm{NO}_{3}\right)_{2}$ with $\mathrm{X}^{-}\left(\mathrm{X}^{-}=\mathrm{BF}_{4}^{-}, \mathrm{PF}_{6}^{-}\right.$, and $\left.\mathrm{ClO}_{4}^{-}\right)$ anions was carried out. During the anion exchange. the infrared spectra show the gradual disappearance of intense $\mathrm{NO}_{3}{ }^{-}$bands $\left(1371 \mathrm{~cm}^{-1}\right)$ and the appearance and growth of new bands $\left(1056 \mathrm{~cm}^{-1}\right.$ for $\mathrm{BF}_{4}^{-}: 830 \mathrm{~cm}^{-1}$ for $\mathrm{PF}_{6}^{-} ; 1098$ $\mathrm{cm}^{-1}$ for $\mathrm{ClO}_{4}^{-}$). For the anion exchange of $\mathrm{NO}_{3}^{-}$with $\mathrm{PF}_{6}^{-}$, 
Table 3. Selected Bond Distance and Angles of $\left[\mathrm{Cu}(\mathrm{L})_{2}\right]\left(\mathrm{NO}_{3}\right)_{2}$

\begin{tabular}{lc}
\hline $\mathrm{Cu}(1)-\mathrm{N}(2) \# 1$ & $2.009(2)$ \\
$\mathrm{Cu}(1)-\mathrm{N}(2)$ & $2.009(2)$ \\
$\mathrm{Cu}(1)-\mathrm{N}(4) \# 2$ & $2.047(2)$ \\
$\mathrm{Cu}(1)-\mathrm{N}(4) \# 3$ & $2.047(2)$ \\
$\mathrm{Cu}(1)-\mathrm{O}(7)$ & $2.524(2)$ \\
$\mathrm{N}(4)-\mathrm{Cu}(1) \# 4$ & $2.047(2)$ \\
$\mathrm{N}(2)+1-\mathrm{Cu}(1)-\mathrm{N}(2)$ & $180.000(1)$ \\
$\mathrm{N}(2)+1-\mathrm{Cu}(1)-\mathrm{N}(4) \# 2$ & $89.80(9)$ \\
$\mathrm{N}(2)-\mathrm{Cu}(1)-\mathrm{N}(4) \# 2$ & $90.20(9)$ \\
$\mathrm{N}(2) \# 1-\mathrm{Cu}(1)-\mathrm{N}(4) \# 3$ & $90.20(9)$ \\
$\mathrm{N}(2)-\mathrm{Cu}(1)-\mathrm{N}(4) \# 3$ & $89.80(9)$ \\
$\mathrm{N}(4)+2-\mathrm{Cu}(1)-\mathrm{N}(4) \# 3$ & $180.000(1)$ \\
$\mathrm{N}(2) \# 1-\mathrm{Cu}(1)-\mathrm{O}(7)$ & $92.51(8)$ \\
$\mathrm{N}(2)-\mathrm{Cu}(1)-\mathrm{O}(7)$ & $87.49(8)$ \\
$\mathrm{N}(4)+2-\mathrm{Cu}(1)-\mathrm{O}(7)$ & $88.34(8)$ \\
$\mathrm{N}(4)+3-\mathrm{Cu}(1)-\mathrm{O}(7)$ & $91.66(8)$ \\
$\mathrm{C}(5)-\mathrm{N}(2)-\mathrm{Cu}(1)$ & $121.5(2)$ \\
$\mathrm{C}(1)-\mathrm{N}(2)-\mathrm{Cu}(1)$ & $120.6(2)$ \\
$\mathrm{C}(17)-\mathrm{N}(4)-\mathrm{Cu}(1) \# 4$ & $121.0(2)$ \\
$\mathrm{C}(21)-\mathrm{N}(4)-\mathrm{Cu}(1) \# 4$ & $121.6(2)$ \\
$\mathrm{N}(5)-\mathrm{O}(7)-\mathrm{Cu}(1)$ & $161.4(2)$ \\
\hline
\end{tabular}

Symmetry transfornations used to generate equivalent atoms: $1-\mathrm{x}-1$, $-v+3,-z+1+2-x-1,-v+2,-z+3 \times y+1, z-1+4 x, v-1, z-1$

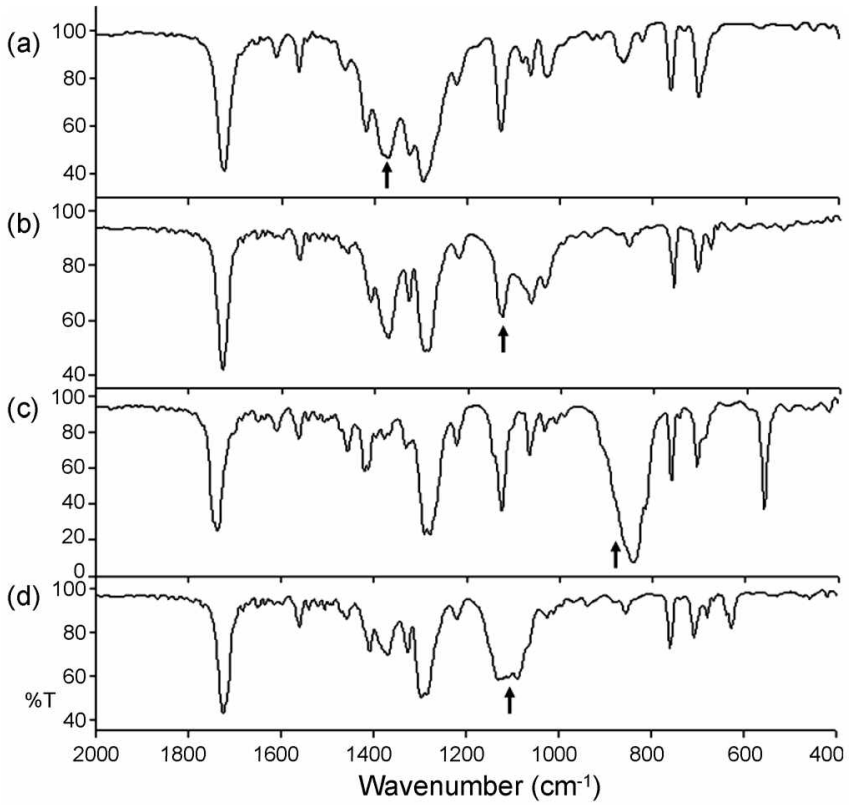

Figure 3. IR (KBr pellet) spectra of $\left[\mathrm{Ag}_{3}(\mathrm{~L})_{2}\right]\left(\mathrm{NO}_{3}\right)_{3}$ (a) and IR bands after the anion exchange $\left[\mathrm{Ag}_{3}\left(\mathrm{~L}_{2}\right]\left(\mathrm{NO}_{3}\right)_{3}\right.$ with $\mathrm{NaBF}_{4}$ for 24 $\mathrm{h}(\mathrm{b}), \mathrm{NaPF}_{\mathrm{D}}$ for $24 \mathrm{~h}$ (c), $\mathrm{NaClO}_{4}$ for $24 \mathrm{~h}(\mathrm{~d})$.

the $\mathrm{NO}_{3}^{-}$peaks disappear completely after $2+\mathrm{h}$. However. for the case of the exchange of $\mathrm{NO}_{3}^{-}$with $\mathrm{BF}_{4}^{-}$or $\mathrm{ClO}_{4}^{-}$. partial anion exchange occurs as shown in Figure 3. That is. $\mathrm{NO}_{3}{ }^{-}$band still exists after anion exchange. For example. the anion exchange of $\left[\mathrm{Ag}_{3}(\mathrm{~L})_{2}\right]\left(\mathrm{NO}_{3}\right)_{3}$ with $\mathrm{BF}_{4}{ }^{-}$was accomplished by $25 \%$. Of course, the other peaks of the spectra remain virtually unchanged. suggesting that the skeletal structure is retained after the anion exchange. The bands of
$560 \mathrm{~cm}^{-1}$ for the exchanged $\left[\mathrm{Ag}_{3}(\mathrm{~L})_{2}\right]\left(\mathrm{PF}_{6}\right)_{3}$ and $625 \mathrm{~cm}^{-1}$ for the $\mathrm{ClO}_{4}^{-}$partial-exchanged species may be each anion bending mode. The robust compound that maintains structural integrity upon the anion exchange may be ascribed to the stable structural properties. For $\left[\mathrm{Cu}(\mathrm{L})_{2}\right]\left(\mathrm{NO}_{3}\right)_{2}$, the similar anion exchanged was attempted. but the anion exchange was not clearly accomplished. Such a fact results from the presence of the weak electrostatic interaction between $\mathrm{Cu}^{2+}$ cation and $\mathrm{NO}_{3}^{-}$anions.

\section{Conclusion}

The skeletal structures of both one dimensional coordination polymers are unprecedented motifs. The flexible triethanolaminetriisonicotinate may be a valuable ligand for the formation of unusual motifs. Further experiments will provide more detailed information on the construction principle as well as the enomous potentials such as catalytic properties. adsorption-desorption of small solvent molecules. and hydrophilicity:

Supporting Materials. TGA data of $\left[\mathrm{Ag}_{3}(\mathrm{~L})_{2}\right]\left(\mathrm{NO}_{3}\right)_{3}$ and $\left[\mathrm{Cu}(\mathrm{L})_{2}\right]\left(\mathrm{NO}_{3}\right)_{2}$.

Acknowledgments. Support for this research was provided by the research fund of Pusan National University in Korea.

\section{References}

1. Blight. B. A.: Wisner. J. A.: Jennings, M. C. Angew. Chem., hut. Ed. 2007, 46,2835 .

2. Gale. P. A. Coord Chem Rev 2001, 213.79.

3. Oh. M.: Mirkin. C. A. Natme 2005. +38.651 .

4. Stang. P. J.: Olenyuk. B. Acc. Chem. Res. 1997.30.502

5. Slone. R. V: Yoon. D. I.: Calhount. R. M: Hupp. T. T. J. An. Chem. Soc. 1995, 117.11813.

6. Chen. B.: Ockitg, N. W. Fronczek, F. R.: Contreras, D. S.; Yaghi. O. M. Inorg. Chem. 2005. H4. 181.

7. Fuijita. M. Chem. Soc. Rev: 1998. 27.417.

8. Jung. O.-S.: Kim. Y. J.: Lee. Y.A.: Park. T. K.: Chae. H. K. J. Am Chent Sox. 2000. 122.9921.

9. Albrecht, M. Angew: Chem. Iht. Ed. 1999. 38. 3463.

10. Jones, C. J. Chem. Soc. Rev. 1998. 27.289.

11. Batten, S. R; Robson, R. Angew: Chem, Int Ed. 1998. 37. 1460 .

12. Constable. E. C. Tetrahedron 1992. 48. 100013.

13. Chui. S. S.-Y.: Lo. S. M.-F.: Charmant. J. P. H.: Orpen. A. G.: Williams. I. D. Science 1999, 283. 1148.

14. Kiang, Y.-H.: Gardener. G. B.: Lee. S.: Xu, Z. J. Am. Chem. Soc. 2000. 122,6871.

15. Braga. D.: Grepioni. F. Ace. Chem. Res. 2000. 33.601.

16. Schmidtchen. F. P.: Berger. M. Chem. Rev: 1997. 97. 1609.

17. Lapointe. R. E.: Roof. G. R.: Abboud. K. A.: Klosin. J. J. An. Chem. Soc. $2000,122.9560$.

18. Mason. S.; Clıtord, T.; Seıb, L.: Kuczera. K.; Bowman-James, K. J. Am. Chem. Soc. 1998. 120,8899.

19. Jung. O-S.: Kim. Y. T.: Lee. Y.-A.: Chae. H. K.: Jan1g. T. H.: Hong. J. horg. Chem. 2001. +0.2105.

20. Jung. O.-S.: Park. S. H.: Kim. K. M.: Tang. H. G. Inorg. Chent. 1998. 37,5781 .

21. Jung. O.-S; Kım, Y. J.: Lee, Y.-A; Park, J. K; Chae, H. K. J. Am. Chem. Soc. $2000,122.9921$. 
22. Jung. O.-S.: Kim. Y. J.: Kim. K. M.: Lee. Y.A. J. Am. Chem. Soc. 2002. 124. 7906.

23. Jung. O.-S.: Kim. Y. J.: Lee. Y.-A.: Park. K. M.: Lee. S. S. Ihorg. Chem. $2003,42.844$.

24. Lee, Y.-A.: Kim, S. A.: Jung. S. M. Junng. O.-S.: Oh. Y. H. Bull. Korean Chem. Soc. 2004, 25,581.

25. Jung. O.-S.: Lee. Y.A.: Kim. Y. J. Chem. Lett. 2002. 1096.

26. Jung. O-S.: Lee. Y.-A.: Kim. Y. J.: Hong. J. Crnst Growth \& Des. 2002. 2. 497.

27. Jung, O.-S Kim, Y. J: Lee. Y.A.: Kante. S. W. Choi, S. N. Gryst. Grow:th \& Des. 2004, A. 23.

28. Park; B. I.: Chun. I. S.; Lee, Y.-A.; Park, K.-M.: Jung. O.-S. horg. Chem. 2006. 15.4310 .

29. Park. B. I.: Kim. Y. J.: Lee. Y.-A.: Park. K.-M.: Jung. O.-S. Bull. Korean Chen. Soc. 2004. 25. 1969.
30. Cha. M. S.: Kim. S. A.: Yoo. K. H.: Park. K.-M.: Tung. O.-S. Bull. Korem Chem. Soc. 2006. 27. 137.

31. Chun1. I. S.: Kwon. T. A.: Yoon1. H. T.: Bae. M. N.: Hon1g. J.: Jung. O.-S. Angew: Chem. Int Ed. 2007. $46,4960$.

32. Yoon. H. J.; Chun. I. S.; Na. Y. M; Lee. Y.-A.; Jung, O.-S. Chem. Conmun. 2007. 492.

33. Hui. L.: Cha. M. S.: Lee. Y.-A.: Lee. S. S.: Jung. O.-S. Inorg. Chent Conmum. 2006. 10.71.

34. Sheldrick. G. M.: SHELAS-97: A Program for Structure Determination; University of Göttingen. Germany, 1997; Sheldrick, G. M. SHELI7-97: A Program for Strueture Refinement: University of Göttingen. Germany, 1997.

35. Yaghi. O. M. Li. H. J. An. Chem. Soc. 1996. HS. 295.

36. Yaghi. O. M.: Li. H.: Davies. C.: Richardson. D.: Groy. T. L. Ace. Chent. Res. 1998.31.474. 